\title{
Exchange rate, income distribution and technical change in a balance-of-payments constrained growth model
}

\author{
Rafael S. M. Ribeiro ${ }^{\text {ał }}$, John S.L. McCombie ${ }^{a}$ and Gilberto Tadeu Lima ${ }^{\text {b }}$ \\ ${ }^{\mathrm{a}}$ Department of Land Economy, University of Cambridge, Cambridge,UK; ${ }^{\mathrm{b}}$ Department of \\ Economics, University of São Paulo, São Paulo, Brazil
}

\begin{abstract}
This paper develops a formal model that accounts for the net effect of an exchange rate devaluation on the long-term balance-of-payments constrained growth rate. Such a model investigates how a currency devaluation impacts on the home country non-price competitiveness via changes in income distribution and the rate of technological innovation. The model is built upon two plausible hypotheses. First, it is assumed that the rate of technological innovation is directly related to the income elasticity of demand for exports and inversely related to the income elasticity of demand for imports. Second, it is assumed that a redistribution of income between labour and capital has an ambiguous direct impact on the income elasticities ratio. The model shows that the net impact of a currency devaluation on growth can go either way depending on the institutional framework of the economy.
\end{abstract}

\section{ARTICLE HISTORY}

Received 19 November 2015

Accepted 18 June 2016

\section{KEYWORDS}

Balance-of-payments constrained growth; income distribution; real exchange rate; technological changes

\section{JEL CODES}

E25; O40; O33

\footnotetext{
CONTACT Rafael S.M. Ribeiro rsmribeiro@gmail.com
} 


\section{Introduction}

In the context of the Post-Keynesian growth literature, this paper explores a number of transmission channels through which a currency devaluation affects the structure of the economy, and hence impacts the long-term growth of output.

After the Second World War, Keynes strongly advocated for the adoption of fixed exchange rates within the rules set forth within the Bretton Woods agreement. In the early 1950s, the fixed exchange rate regime worked quite well because the United States (US) had the largest share of the world's official gold reserves. However during the 1960s this scenario began to change drastically. The low interest rates employed by the US government drained their gold reserves, thereby reducing their financial account surplus. The Vietnam Warrelated expenditures and US foreign aid to other countries were cited as the main cause of the country's ever-growing fiscal and current account deficits. The US also struggled with a sharp increase in the price of some inputs and the oil crisis (Glyn et al, 1990).

In 1971, the US brought the Bretton Woods system to an end by unilaterally suspending the conversibility of the US dollar to gold. At the time, mainstream economists claimed that countries would be better off with a floating exchange rate regime. They believed that such a regime would correct real exchange rate (RER) misalignments automatically, thereby preventing a balance-of-payments (BP) crisis and bringing autonomy back to monetary policy. The conventional wisdom argues that in this regime relative prices remain practically unchanged due to the so-called neoclassical law of one price. Underlying such an argument is a strong belief that free, self-regulating markets, instead of governments, can determine more efficiently the equilibrium exchange rate, yielding the best possible result for the economy as a whole. Therefore, the floating exchange rate regime should be the best way to avoid a BP crisis and promote economic growth. Thus, it is clear that, according to this school of thought, the exchange rate adjusts itself endogenously and, consequently, can play no role as a macroeconomic policy tool.

At a theoretical level, the law of one price requires infinite price elasticities of demand for exports and imports, and negligible income elasticities of demand for exports and imports. As a result, growth cannot be $\mathrm{BP}$ constrained. However, 'since the onset of floating exchange rates in 1972, it is clear from the historical evidence that the massive nominal exchange rate movements that have taken place have not rectified balance-of-payments disequilibria' (McCombie and Thirlwall 1999, p. 51). Empirical studies strongly suggest that price elasticities are rather low, statistically non-significant or carry unexpected signs, whereas the opposite is observed for the income elasticities (Carvalho and Lima 2009; Gouvea and Lima 
2013; Léon-Ledesma 2002; Moreno-Brid 1999; Moreno-Brid and Perez 1999; Perraton 2003; Razmi 2005; Soukiazis et al, 2013). It is income that adjusts to correct BP misalignments, not relative prices.

Since no country can run an ever-increasing level of overseas debt to GDP ratio, the balance-of-payments constrained growth (BPCG) rate is the maximum a country is permitted to grow. ${ }^{1}$ Thirlwall (1979) demonstrates that a country's equilibrium growth rate is determined by the growth of world income and the trade income elasticities ratio reflecting the non-price competition factors affecting its performance in the international trade, such as technological capabilities, tastes, stock of knowledge, and so on. In this context, relative prices have been pushed aside from the center of the discussion on growth. ${ }^{2}$ Thirlwall (2011, p. 232) states 'that a once-for-all depreciation (or devaluation) will not put a country on a permanently higher growth rate. For this to happen, the depreciation would either have to be continuous, or affect the parameters of the model favourably'. However, Thirlwall's (1979) standard growth model assumes income elasticities to be exogenous and the growth of relative prices is mitigated over time, and hence the RER plays no role in determining the long-term growth rate.

Nonetheless, even though a very weak, or no, relationship is found between relative prices and the volume of exports and imports in the trade demand functions, a statistically significant connexion between a devalued currency and higher growth rates has been observed in the literature. There is a vast range of empirical evidence demonstrating a meaningful connection between exchange rate volatility and a poor growth performance for several countries since the adoption of the floating exchange rate regime in the 1970s (Aguirre and Calderón, 2005; Dollar 1992; Razin and Collins 1997;). The literature also shows that countries that sustained their currency at competitive levels over relatively long periods experienced, by and large, higher growth rates (Aguirre and Calderón 2005; Dollar 1992; Gala 2007; Loayza et al, 2004; Rodrik, 2007; Sachs 1985). In light of Thirlwall's growth model, these results indicate that the level of the RER may have some impact on a country's income elasticities.

\footnotetext{
${ }^{1}$ Setterfield (2006) and McCombie (2011) convincely argue that the supply side, given by the growth of the productive potential, adjusts to the balance-of-payments constrained growth rate.

${ }^{2}$ An exception to this is Porcile and Lima (2010). They proposed a model where the RER actually plays an important role in a balance-of-payments constrained growth model. In their model the level of employment and the elasticity of labor supply can prevent currency appreciation, thereby impacting directly on income distribution and growth in developing countries.
} 
In this spirit, a more recent literature on BPCG models explores the links between a competitive currency and non-price competition factors. Barbosa-Filho (2006) says that a devalued RER over a prolonged period of time favors the relative prices of tradable goods, hence promoting a structural change in the economy, since technological progress and productivity are usually higher in these sectors. In considering Thirlwall's (multi-sectoral) Law, Araújo (2012) discusses how a currency appreciation affects a country's equilibrium growth rate. He shows that the country might lose its comparative advantage in a sector due to currency appreciation, and hence damage its capacity to export. As a result, the country undergoes an unfavorable structural change slowing down its equilibrium growth rate. Ferrari et al (2013) assume a two-sector economy producing only high- and low-technology tradables, and suggest that currency devaluation increases the high-technology tradables share of total exports and decreases the high-technology tradables share of total imports, thus raising the country's elasticities ratio. Missio and Jayme Jr (2012) claim that a currency devaluation, by increasing the profit share to the detriment of real wages, accelerates technological progress, improves the competitiveness of exports, and modifies the country's specialization pattern through changes in the income elasticities of demand for exports and imports ratio, therefore boosting long-term growth.

However, the literature has ignored how changes in income distribution may impact on consumption patterns, the production decisions of domestic firms, and the non-price competitiveness of a country. Assuming that consumers tend to change their preferences towards more luxury than necessity goods as their income grows, an increase in the wage share of income at the expense of the profit share induces changes in average consumer preferences, hence affecting qualitatively a country's imports. ${ }^{3}$ Moreover, changes in income inequality might also encourage domestic firms to specialize in the production of labor- or capital-intensive goods, depending on the source driving the redistribution of income. Here, we consider the hypothesis that the RER affects not only a country's technological progress, but also its income distribution, thus changing its non-price competitiveness and, consequently, its long-term growth rate. Therefore, we set out a more general theoretical framework that enables us to assess the conditions under which a currency devaluation might

\footnotetext{
${ }^{3}$ The economic literature indicates that all goods can be classified according to their income elasticity of demand, as follows:

- inferior goods: negative income elasticity;

- necessity goods: income elasticity between 0 and 1 ; and

- luxury (or superior) goods: income elasticity greater than 1.

In this we do not consider the existence of inferior goods, as the income elasticities are strictly positive.
} 
either boost or harm long-term growth. Such a model seeks to demonstrate that the impacts of a currency devaluation on the growth performance of the economy depends greatly on the institutional framework of the economy and hence there is no practical guide or one-size-fitsall policy recommendation regarding the effects of a currency devaluation on growth. Instead, our model suggests that policy makers should carefully evaluate the idiosyncrasies of each economy in order to obtain a better diagnosis concerning the effectiveness of an eventual currency devaluation policy, since such a policy, if not applied correctly, may have unwanted effects.

\section{The model}

Let us assume that the global economy consists of two different countries: a rich foreign country and a poor home country. The foreign country is an economy that issues the international currency and the home country is an economy facing a BP constraint. For convenience, there are no international capital flows between the two countries and no government activities. ${ }^{4}$ The foreign country is a two-sector economy which produces and exports consumption goods and industrial intermediate inputs. The home country is a onesector economy that produces and exports only one sort of consumption good and there is imperfect substitutability between the foreign and domestic consumption goods. It is also assumed that the home country imports consumption goods and industrial intermediate inputs from the foreign country. That is to say, the home country imports are disaggregated in two different categories, namely, imported consumption good $\left(M^{c}\right)$ and imported intermediate goods $\left(M^{r}\right)$, that is, $M=M^{c}+M^{r}$. By doing so, we have now an extended BP identity:

$$
P_{d} X=E\left(P_{f} M^{c}+P_{f}^{r} M^{r}\right)
$$

where $X$ is the quantity of exports, $P_{d}$ is the domestic price, $P_{f}$ is the imported consumption goods price in foreign currency, $P_{f}^{r}$ is the imported intermediate goods prices in foreign currency, and $E$ is the nominal exchange rate (that is, the home price of the foreign currency). Hereafter, let us assume $P_{f}=P_{f}^{r}$ over time. In the rates of change:

\footnotetext{
${ }^{4}$ McCombie and Thirlwall (1997) and Moreno-Brid (1998) estimate the impact of financial inflows on the equilibrium BPCG rate.; Thirlwall (2011) points out that even large flows of capital make little quantitative difference to the predictions of the equilibrium BPCG rate. We also assume no government activities in order to keep both focus and the model tractable. For details on the importance of internal imbalances and fiscal debt on BPCG models see, for example, Soukiazis et al $(2013,2014)$.
} 


$$
p_{d}+x=e+p_{f}+\phi_{c} m^{c}+\left(1-\phi_{c}\right) m^{r}
$$

where $\phi_{c}=M^{c} / M ;\left(1-\phi_{c}\right)=M^{r} / M$.

The export demand function is:

$$
X=\left(\frac{P_{d}}{P_{f} E}\right)^{\eta} Z^{\varepsilon} \quad \eta<0, \varepsilon>0
$$

where $Z$ is the level of the foreign income, $\eta$ is the price elasticity of demand for exports, and $\varepsilon$ is the income elasticity of demand for exports. In the rates of change:

$$
x=\eta\left(p_{d}-p_{f}-e\right)+\varepsilon z
$$

The import demand functions are:

$$
\begin{aligned}
& M^{c}=M_{0}^{c}\left(\frac{E P_{f}}{P_{d}}\right)^{\psi} Y^{\pi_{c}} \quad \psi<0, \pi_{c}>1 \\
& M^{r}=\mu Y
\end{aligned}
$$

where $M_{0}^{c}$ and $\mu$ are constants, $\psi$ is the price elasticity of demand for imports, and $\pi_{c}$ is the income elasticity of demand for imported consumption goods. Equation (5) is a stable multiplicative demand function for imported consumption goods, whereas Equation (6) expresses a linear relationship (one can view it as a linear approximation to a long term multiplicative function at a specific point in time). It will be assumed here that technological innovations are neutral with respect to the amount of intermediate inputs utilized in the production process, and hence the ratio of imported intermediate goods to domestic output $\left(M^{r} / Y\right)$ does not change over time. In this scenario, it is reasonable to assume the coefficient $\mu$ is constant.

In the rates of change, Equations (5) and (6) respectively are given by:

$$
\begin{aligned}
& m^{c}=\psi\left(e+p_{f}-p_{d}\right)+\pi_{c} y \\
& m^{r}=y
\end{aligned}
$$

If we allow equations (8), (7) and (4) into (2), we find the growth rate of the revisited model:

$$
y=\frac{\varepsilon Z+\left(1+\eta+\phi_{c} \psi\right)\left(p_{d}-p_{f}-e\right)}{\pi}
$$


where $\pi=\phi_{c}\left(\pi_{c}\right)+\left(1-\phi_{c}\right)$ and $\left(1+\eta+\phi_{c} \psi\right)<0$ is the extended Marshall-Lerner condition which guarantees that a RER devaluation spurs growth in the short term. Assuming that relative prices do not change in the long term, $\left(p_{d}-p_{f}-e\right)=0$, we can derive the equilibrium BPCG rate from Equation (9):

$$
y_{B P}=\frac{\varepsilon Z}{\pi}
$$

Equation (10) describes the widely known Thirlwall's Law. This Law states that domestic growth is directly related to the growth rate of foreign demand. It also states that the growth rate of a country's output depends positively on its existing non-price competition factors, here expressed by the ratio $\varepsilon / \pi$. This ratio reflects disparities between countries with respect to factors determining the demand for a country's exports and imports, such as technological capabilities, product quality, stock of knowledge, and consumer preferences, for instance. Before we continue, it is worth noting that the income elasticity of demand for total imports $(\pi)$ is given by the weighted average of income elasticities of demand for imported consumption goods $\left(\pi_{c}\right)$ and imported intermediate inputs, which is equal to unity. In this model it is assumed that the impact of changes in the RER and on the weight $\phi_{c}$ is negligible.

\subsection{Endogenising income elasticities}

In this analysis, we investigate the net effect of a currency devaluation on the home country's non-price competitiveness via changes in the technology gap and income distribution.

To commence we assume that there are technological disparities between the foreign and home countries. The foreign country pushes forward the technological frontier while the home country is lagging behind. Therefore, the inverse of the technology gap between foreign and home countries $(S)$ can be proxied by:

$$
S=\frac{S_{d}}{S_{f}}, \quad S \in(0,1)
$$

where $S_{d}$ and $S_{f}$ denote the level of technological capabilities of the home and the foreign countries respectively. The level of technological capabilities denote the stock of knowledge of the economy. The higher the economy's stock of knowledge the greater is its ability to create technological innovations and hence to raise the productivity of labor. It should be noted that in our model only the level of foreign technological capabilities is exogenous. 
It is also assumed that there are two classes in the domestic economy, capitalists and workers. Following the tradition of Marx and Kalecki (1971), we assume that workers earn only wages and spend all their income on consumption, whereas capitalists earn profits and consume only part of their income, thus implying that the savings of the economy depends on capitalists' retained profits. Since in most developing countries the savings propensities of the workers, excluding CEOs, is very small, the division in the Kaleckian growth model between the shares held by profits and wages still holds.

In an economy that allows for imported intermediate inputs into the unit production cost, the wage share of income can be defined as follows:

$$
\sigma_{L}=\frac{W}{P_{d}} \frac{1}{a}=1-\sigma_{K}-\left(\frac{E P_{f}}{P_{d}} \mu\right)=1-\sigma_{K}-\Theta \mu
$$

where $\sigma_{L}$ and $\sigma_{K}$ are the share of wages and profits in income respectively, $\Theta=E P_{f} / P_{d}$ is the RER, $W$ is the average nominal wage and $a$ is the labor productivity. Once we know the wage share $\left(\sigma_{L}\right)$ and the intermediate inputs share $(\Theta \mu)$, the profit share $\left(\sigma_{K}\right)$ is determined as a residual (a residual in the sense that domestic firms are price-takers and have no control over the imported intermediate goods share or over the wage share which is determined in the labor market). Now we must address two key hypotheses of the model concerning the impact of technological change and income distribution on a country's non-price competitiveness.

The first assumption is that an increase in the home country's relative technological capabilities improves its non-price competitiveness (that is $S \rightarrow \uparrow \varepsilon / \pi$ ). The higher the level of technological capabilities of the economy the higher the capacity of domestic firms to distinguish their products and make them more attractive relative to the products produced in other countries with a lower stock of knowledge. Hence, an increased level of technological capabilities also raises the quality of the products produced domestically.

Since the quality and attractiveness of domestic goods is proxied by the trade elasticities ratio we have $S$ and the trade elasticities ratio $\varepsilon / \pi$ are positively related. This hypothesis is strongly supported by the literature at theoretical and empirical levels. Fagerberg (1988) questions the traditional wisdom by suggesting that technology and the ability to compete on delivery are the main factors affecting differences in international competitiveness, rather than relative unit labor costs reflecting differences in price-competitiveness. He also finds evidence for 15 industrial countries during the period 1960-83 supporting his arguments. Amable and Verspagen (1995) find strong empirical evidence of the positive impact of technological progress on the exports-market shares for 5 industrialized countries and 18 
industries over the period 1970-91. Hughes (1986) hypothesizes that there is a two-way relationship between exports and innovation due to differences in the specificities of demand between export and domestic markets in a study for 46 UK manufacturing industries. LéonLedesma (2002) extends the Dixon and Thirlwall (1975) model and find a positive and statistically significant impact of technological innovations on exports and labor productivity growth for 17 OECD countries from 1965-94. Araujo and Lima (2007) developed a disaggregated multi-sectoral version of Thirlwall's Law, where a country can reach higher growth rates only by specializing in sectors with relatively high (low) income elasticities of demand for exports (imports). Gouvea and Lima (2010, 2013) test the multi-sectoral model and their results, in general, support the hypothesis that goods from relatively high technology-intensive sectors have higher (lower) income elasticities of demand for exports (imports).

Another key assumption is that changes in income distribution affect the consumption pattern and, consequently, a country's non-price competitiveness (that is $\sigma_{L} \rightarrow \uparrow \downarrow \varepsilon / \pi$ ). From a historical perspective, Linder observed in 1961 that international trade in manufactured goods amongst developed countries was heavily determined by within-country income levels and income distribution (Francois and Kaplan 1996). He postulated that, given the existence of non-homothetic preferences, the more unequal the personal income distribution of a country, the greater its expenditures on luxury goods (Francois and Kaplan 1996). ${ }^{5}$ Some Latin American Structuralists argue that the high levels of income inequality observed in the region led to stark differences in the patterns of consumptions between the lower and the upper classes. As the latter used to imitate the pattern of consumption of European developed countries, a meaningful part of domestic savings leaked out of those countries to sustain the imports of superfluous and highly technological products from developed countries (Furtado 1968, 1969; Tavares and Serra 1976). A more recent literature emphasizes the impact of an increasing income inequality on foreign trade (Bohman and Nilsson 2007; Dalgin et al 2008; Mitra and Trindade 2005). They conclude that, given the non-homothetic preferences, more unequal countries tend to export relatively more necessity goods and import more luxury goods. Changes in income distribution reshape patterns of consumption and foreign trade.

\footnotetext{
${ }^{5}$ In 1857 the statistician Ernst Engel presented his seminal theory on consumer behavior. He states that as income grows consumers tend to substitute luxury for necessity goods, where luxury goods have an income elasticity of demand greater than unity and necessity goods have an income elasticity of demand less than unity. Here non-homothetic preferences basically mean that the proportion of income that consumers spend on luxury and necessity goods varies as income increases.
} 
It is notable that a changing consumption pattern may have inter- and intra-sectoral effects on the composition of the consumption goods imported and exported by the home country. The inter-sectoral effect accounts for the substitution of necessity for luxury goods-or viceversa (after a redistribution of income). Such an effect can be addressed by a multi-sectoral Thirlwall's Law, as developed by Araújo and Lima (2007). However, since we are assuming that the home country exports and imports only one type of consumption good with imperfect substitutability between them, we do not consider the inter-sectoral effect. Here we assume only the intra-sectoral effect, which implies that changes in the income distribution encourage foreign and domestic firms to modify the quality and design of their products. Such changes in the non-price competitiveness of foreign and domestic goods, due to the income redistribution, will cause changes in the income elasticities ratio.

Changes in the consumption pattern due to the redistribution of income affect separately the income elasticity of demand for imports and the income elasticity of demand for exports. That said, let us discuss first the intra-sectoral effect on a home country's imports, that is, the impact of income distribution on the income elasticity of demand for imports. It is assumed that an increased wage share reduces the capitalist's desire or predisposition to buy luxury goods (and increases their desire for necessity goods) as it increases a worker's desire for luxury goods (at the expense of their desire for necessity goods). Therefore, we have two different scenarios: (i) if the reduction in the capitalist's desire for luxury goods caused by an increased wage share over-compensates the increase in a worker's desire for luxury goods, then a higher wage share reduces the aggregate consumers desire for luxury goods in the home country; (ii) if an increase in a worker's desire for luxury goods outweighs the decrease in the capitalist's desire for luxury goods, then an increased wage share increases the aggregate consumers desire for luxury goods in the home country.

However, a simple change in the consumer's desire or predisposition towards luxury goods vis-à-vis necessity goods does not have any actual impact on the income elasticity of the demand for imports. The elasticity will change only if the foreign developed economy also has the capacity of constantly transforming the quality of its exports and its productive structure in order to match the changing consumer demand in its markets (Setterfield 1997). In other words, a change in the home country's income elasticity of imports is caused by an intra-sectoral transformation in its imported consumption goods undertaken by foreign firms in their pursuit for a higher market share. That said, in scenario (i) in which the aggregate consumers desire for luxury goods in the home country is reduced due to a rising wage share, the foreign country will meet the requirement of its market by simplifying the quality and 
design of its exports, thus lowering the home country's income elasticity of demand for imports. In scenario (ii) where an increased wage share increases the aggregate consumers desire for luxury goods in the home country, the foreign economy will be able to improve the non-price competitiveness of its exports and hence increase the home country's income elasticity of demand for imports. In short, the impact of a changing consumption pattern on the income elasticity of imports is ambiguous.

As for the intra-sectoral impact on the home country's exports, that is, the relationship between income distribution and income elasticity of exports, the effect is also ambiguous. Lower real wages can reduce the wage share and encourage domestic firms to specialize in the production of labor-intensive goods, which traditionally tend to have a lower income elasticity of demand. However, if a decrease in the wage share is caused by an increase in labor productivity, then domestic firms might specialize in more capital-intensive goods, which tend to have a higher income elasticity of demand. It is worth noting that the demand structure of the foreign country does not affect the home country's income elasticity of exports. Since it is assumed that the home country produces and exports only one sort of consumption good, a worsened income distribution impacts negatively on the income elasticity of exports, independently of the demand structure of the foreign country. To sum up, the impact of a change in the income distribution also has an ambiguous effect on the home country's income elasticity of exports.

As a result of these hypotheses, it can be said that trade elasticities are a function of the consumption pattern of households $(C)$ and the inverse of the technological gap between the foreign and home countries $(S)$, that is, $\varepsilon / \pi=\varepsilon / \pi(C, S)$, where $(\varepsilon / \pi)_{C} \gtrless 0$ and $(\varepsilon / \pi)_{S}>$ 0 . Moreover, the consumption pattern is a positive function of the wage share, $C=C\left(\sigma_{L}\right)$, where $C_{\sigma_{L}}>0$, as it is assumed that a worker's propensity to consume is higher than the capitalist's propensity to consume. Thus, we can redefine the trade elasticities as $\varepsilon / \pi=$ $\varepsilon / \pi\left(\sigma_{L}, S\right)$, where $(\varepsilon / \pi)_{\sigma_{L}} \gtrless 0$ and $(\varepsilon / \pi)_{S}>0$. Ergo, for simplicity, the country's elasticity ratio can be described as a linear function of the wage share of its workers in income and its relative technological capabilities, as follows:

$$
\frac{\varepsilon}{\pi}=\beta_{0}+\beta_{1} \sigma_{L}+\beta_{2} S
$$

Here it will be assumed without loss of generality that $\beta_{0}, \beta_{1}, \beta_{2}>0 . \beta_{0}>0$ is sufficiently high in absolute value in order to rule out the possibility of a negative elasticity ratio. Even though the sign of $\beta_{1}$ is ambiguous, here it is assumed that $\beta_{1}>0$, which means 
that any negative effect of a possible increase in a country's total consumer demand for luxury goods on the income elasticity of imports, caused by an increased wage share, is not enough to mitigate the positive impact of a more even distribution of income on the income elasticity of exports; and $\beta_{2}>0$ falls in line with the hypothesis that a country's relatively high technological capabilities impact positively on its non-price competitiveness. Last, note that Equation (13) depends on the existence of the demand function for imported consumption goods given by Equation (5). If, for instance, we assume that the home country only imports imported intermediate inputs, then the income elasticity of demand for imports remains constant and equal to unity $\pi=1$. In this case, several transmission channels, specified above through which the RER affects long-term growth, would be nullified.

However, in order to analyze the net effect of the RER on the elasticities ratio and consequently on the long-term growth rate, we must describe how technological innovation and income distribution interact over time and also the role of the RER in such a dynamic.

\subsection{Technological progress}

Let us assume that the rate of change of technological progress can be expressed as:

$$
\dot{S}=\alpha_{0}+\alpha_{1} \sigma_{K}-\alpha_{2} \sigma_{K}^{2}-\alpha_{3} S
$$

where $\dot{S}$ is the derivative of $S$ with respect o time, and $\alpha_{0} \lessgtr 0$ and $\alpha_{1}, \alpha_{0}, \alpha_{3}>0$ are parameters. There are two classes in the economy, workers and capitalists. Workers earn only wages and consume all their income. Capitalists earn the profits of enterprises and save a constant fraction of their income. Following Lima (2004), we assume a non-linear relationship between the profit share and technological progress. Since there is no financial market in the model, investments in technology are funded from the profit share. At low levels of profit rate the capitalists have incentives to invest in technology but run into a saving shortage to do so. As the profit share in income increases the capitalists raise their capacity to innovate and the technology gap reduces until the point where higher profit rates become ineffective to boost technological progress. At the high levels of profit share of income, the capitalists lack the incentives to introduce new technologies. We also assume that the rate of change of technical progress is a negative function of the inverted technology gap. 'This happens because the higher the technology gap, the higher the opportunities for learning related to imitation, international technological spillovers and catching up' (Cimoli and Porcile 2014, p. 217). 
Substituting $\sigma_{K}$ with its very definition $\left(1-\sigma_{L}-\Theta \mu\right)$ in (14) and assuming $\alpha_{1}=\alpha_{2}$ for convenience, we have after some rearrangements:

$$
\dot{S}=\rho_{0}+\rho_{1} \sigma_{L}-\alpha_{2} \sigma_{L}^{2}-\alpha_{3} S
$$

where $\rho_{0}=\alpha_{0}+\alpha_{2}(1-\Theta \mu) \Theta \mu$ and $\rho_{1}=\alpha_{2}(1-\Theta \mu)$. We also assume henceforth $\rho_{0}<0$ without loss of generality, which means $\alpha_{0}$ is negative and sufficiently large in absolute value. By considering $\alpha_{0}<0$, we assume the autonomous technological progress in the foreign country grows faster than in the home country.

The locus $\dot{S}=0$ describes the relation between technological progress and the wage share, provided there is a constant technology gap over time. This equation is given by:

$$
S=\frac{\rho_{0}}{\alpha_{3}}+\frac{\rho_{1}}{\alpha_{3}} \sigma_{L}-\frac{\alpha_{2}}{\alpha_{3}} \sigma_{L}^{2}
$$

Accordingly, we can picture an inverted U-shaped curve relating the wage share and technological progress. Taking the first derivative we obtain the point of maximum:

$$
\sigma_{L}^{*}=\frac{\rho_{1}}{2 \alpha_{2}}=\frac{1-\Theta \mu}{2}
$$

since $\Theta \mu \in(0,1)$, then $\sigma_{L}^{*} \in(0,1 / 2)$. Once the second derivative is negative, $-2 \alpha_{2} / \alpha_{3}<0$, then $\sigma_{L}^{*}$ is a point of maximum. Assuming Equation (15) has two distinct real roots, equation (16) can be illustrated as in Figure 1.

\section{[FIGURE 1 ABOUT HERE]}

\subsection{Functional income distribution}

Let us assume that the time derivative of the wage share of income is a positive function of the gap between the wage share expected by workers $\left(\sigma_{L}^{e}\right)$ and the current wage share, as follows:

$$
\dot{\sigma}_{L}=\theta\left(\sigma_{L}^{e}-\sigma_{L}\right)
$$

where $\theta>0$ is an adjustment parameter. Now, we must endogenise $\sigma_{L}^{e}$. To do so, let us redefine first $\sigma_{L}^{e}$, as follows:

$$
\sigma_{L}^{e}=1-\sigma_{K}^{e}-\Theta \mu
$$


where $\sigma_{K}^{e}$ is the residual expected profit share with respect to the wage share expected by the workers $\left(\sigma_{L}^{e}\right)$ which, in turn, depends on the bargaining power of workers. Once $\Theta \mu$ is constant at first and exogenously given, that is, neither workers nor capitalists have any influence on the imported intermediate inputs share of variable unit costs of production, then we can say $\sigma_{L}^{e}$ and $\sigma_{K}^{e}$ are inversely related.

If $\sigma_{L}^{e}$ depends positively on the bargaining power of workers, then $\sigma_{K}^{e}$, on the other hand, is negatively related to the bargaining power of workers:

$$
\sigma_{K}^{e}=\omega_{0}-\omega_{1}(l-n)
$$

where $l$ is the rate of change of employment, $n$ is the exogenously given growth of the labor force and $\omega_{0}, \omega_{1} \geq 0$ are parameters. The underlying assumption in Equation (20) is that the higher the growth of the employment rate, the higher the bargaining power of workers. Plugging equations (20) and (19) into (18) we have:

$$
\dot{\sigma}_{L}=\theta\left[1-\omega_{0}+\omega_{1}(l-n)-\Theta \mu-\sigma_{L}\right]
$$

From the definition of the long-term rate of change of labor productivity, we have the following identity:

$$
l=y_{B P}-\hat{a}
$$

where $\hat{a}$ is the growth rate of labor productivity. Following Kaldor (1966), we contend that the growth of labor productivity is positively related to the growth of output (the so-called Verdoorn's Law). Drawing upon the formalization of Kaldor's theory proposed by Dixon and Thirlwall (1975), we have the following equation in the long term:

$$
\hat{a}=a_{0}+\lambda y_{B P}
$$

where $a_{0}$ is rate of autonomous productivity growth, and $\lambda>0$ is the Verdoorn coefficient.

If we substitute Equations (23), (22), and (13) into Equation (21), we obtain:

$$
\dot{\sigma}_{L}=\theta\left\{1-\omega_{0}+\omega_{1}\left[(1-\lambda)\left(\beta_{0}+\beta_{1} \sigma_{L}+\beta_{2} S\right) z-a_{0}-n\right]-\Theta \mu-\sigma_{L}\right\}
$$

From Equation (24), in the long-term we expect the real wage and labor productivity will grow at the same rate. Note in Equation (24) that the Verdoorn coefficient can be set to zero without loss of generality. However, a Verdoorn coefficient equal to zero over-estimates the equilibrium value of the wage share, hence affecting the level of relative technological 
capabilities and the equilibrium growth rate. Therefore, it is important to include the Verdoorn coefficient within our theoretical framework, as future works testing the theoretical model should take into account the Verdoorn effect in order to obtain more accurate results.

Therefore, in the locus $\dot{\sigma}_{L}=0$, the equation that describes the relationship between technology gap and wage share is given by:

$$
S=\frac{\gamma_{0}}{\gamma_{2}}+\frac{\gamma_{1}}{\gamma_{2}} \sigma_{L}
$$

where $\quad \gamma_{0}=\Theta \mu-1+\omega_{0}-\omega_{1}\left[(1-\lambda) \beta_{0} z-a_{0}-n\right] \gtrless 0, \quad \gamma_{1}=1-\omega_{1}(1-\lambda) \beta_{1} z \gtrless 0$, $\gamma_{2}=\omega_{1}(1-\lambda) \beta_{2} z>0$. Here we assume $\gamma_{0}>0$ without loss of generality. It is also assumed $\gamma_{1}>0$ which means $z<1 / \omega_{1}(1-\lambda) \beta_{2}$ is the condition to be fulfilled. Therefore, given these constraints on the parameters, we make sure that the Equation (25) falls within a meaningful economic domain, as represented in Figure 2.

\section{[FIGURE 2 ABOUT HERE]}

\subsection{The technology gap and income distribution dynamics}

Figure 3 illustrates the non-trivial solutions for the system determined by Equations (16) and (25)

\section{[FIGURE 3 ABOUT HERE]}

Now we must analyze the local stability conditions around the equilibrium points $E_{1}$ and $E_{2}$. From Equations (15) and (24) we form a 2x2 non-linear dynamical system for the technology gap and income distribution. The linear version of the system is formed by the terms of the Jacobian matrix (see Appendix):

$$
\left[\begin{array}{c}
d \dot{S} / d t \\
d \dot{\sigma}_{L} / d t
\end{array}\right]=\left[\begin{array}{cc}
-\alpha_{3} & 2 \alpha_{2}\left(\sigma_{L}^{*}-\sigma_{L E i}\right) \\
\theta \gamma_{2} & -\theta \gamma_{1}
\end{array}\right]\left[\begin{array}{c}
S-S_{E i} \\
\sigma_{L}-\sigma_{L E i}
\end{array}\right]
$$

where $S_{E i}$ and $\sigma_{L E i}$, for $i=\{1,2\}$, stand for the generic equilibrium values of $S$ and $\sigma_{L}$, respectively. Before we start the stability analysis, let us follow Lima (2004) and divide the domain into the low wage share (LWS) and the high wage share (HWS) regions. The LWS region $\sigma_{L E}<\sigma_{L}^{*}$ means the innovation process is wage-led, since $\partial \dot{S} / \partial \sigma_{L}=2 \alpha_{2}\left(\sigma_{L}^{*}-\right.$ $\left.\sigma_{L E}\right)>0$, whereas in the HWS region $\sigma_{L}^{*}<\sigma_{L E}$, and the technological progress, becomes 
profit-led, for $\partial \dot{S} / \partial \sigma_{L}<0$. As we can see in Figure 3, E1 is placed within the LWS region, whereas $E 2$ is in the HWS region.

First, we will analyze the stability conditions around the point $E 1$ in the LWS region. For the point $E 1$ in the LWS region, the trace of the Jacobian matrix is negative $\left(-\alpha_{3}-\theta \gamma_{1}<\right.$ $0)$ and the determinant is ambiguous $\left[\alpha_{3} \theta \gamma_{1}-\theta \gamma_{2} 2 \alpha_{2}\left(\sigma_{L}^{*}-\sigma_{L E 1}\right) \lessgtr 0\right]$, given $\sigma_{L}^{*}>\sigma_{L E 1}$. If the determinant is negative, then $E 1$ is a saddle-point; otherwise, it is a stable point. Here, it is assumed, without loss of generality, that the determinant is negative and $E 1$ is a saddlepoint.

The same analysis can be extended to the point $E 2$ in the HWS region. Since the trace of the Jacobian matrix in $E 2$ is also negative and given $\sigma_{L}^{*}<\sigma_{L E 2}$ the determinant is unambiguously positive, the point E2 is locally stable.

\section{Real exchange rate, technological progress and income distribution}

The standard BPCG model assumes that the growth rate of relative prices converges to zero over time, that is, $e+p_{f}-p_{d} \rightarrow 0$. Given a rise in the rate of change of the nominal exchange rate $\left(e+p_{f}>p_{d}\right)$, the inflation rate will lag behind at an increasing rate of change over time until it matches the growth of foreign prices in terms of the domestic currency in the long-term $\left(e+p_{f}=p_{d}\right)$. As a result, long-term relative prices will cease to change and the level of the RER will be higher than its initial value. In other words, we are assuming here that a rise in the level of the nominal exchange rate only partially passes through into the domestic price level. In terms of the model developed here, any nominal exchange rate shock raises permanently the RER, $\Theta$, until it stabilises at a higher level in the long-term.

That said, now we must see how a currency devaluation impacts on both loci $\dot{S}=0$ and $\dot{\sigma}_{L}=0$. As for the locus $\dot{S}=0$ described by Equation (16), we see that a currency devaluation shifts the curve upwards, since the intercept of Equation (16), $\rho_{0}$, is positively related to $\Theta$. That is, $d \rho_{0} / d \Theta=\alpha_{2} \mu(1-2 \Theta \mu)>0$ for $\Theta \mu<1 / 2$. Figure 4 illustrates such a dynamic. The dashed-line representing the locus $\dot{S}_{0}=0$ is the initial curve whereas the solid line representing the locus $\dot{S}_{1}=0$ is the new curve following a currency depreciation.

\section{[FIGURE 4 ABOUT HERE]}

As for the locus $\dot{\sigma}_{L}=0$ described in Equation (25), since the level of the RER is positively related to nothing but its intercept, a currency devaluation will shift the curve upwards 
without affecting its slope. More formally, from Equation (25) we have $d S / d \Theta=$ $\mu / \omega_{1}(1-\lambda) \beta_{2} z>0$. Figure 5 shows what happens with the locus $\dot{\sigma}_{L}=0$.

\section{[FIGURE 5 ABOUT HERE]}

Once again, the grey dotted line $\dot{\sigma}_{L 0}=0$ is the initial curve and the black one $\dot{\sigma}_{L 1}=0$ is the new locus following a devaluation. Figure 6 shows the impact of an increase in $\Theta$ on the dynamics between technological progress and income distribution in the long-term.

\section{[FIGURE 6 ABOUT HERE]}

Before we analyze the dynamics in Figure 6, we must determine how the wage and profit shares respond to changes in the RER.

Assuming that firms set the price level according to a mark-up over prime costs, that is, unit labor cost and intermediate goods, , the price level is given by:

$$
P_{d}=T\left(\frac{W}{a}+P_{f} E \mu\right)
$$

Equation (27) demonstrates an inverse relationship between the mark-up and the wage share.

Following Blecker (1989), let us redefine the mark-up as a function of the RER. A devalued currency increases the monopoly power of domestic firms and enables them to raise their mark-up:

$$
T=\delta \Theta
$$

where $\delta>0$ is a parameter.

If we divide the mark-up price Equation (27) by domestic prices, substitute Equation (28) in the mark-up factor, and solve for $\sigma_{L}$, then we obtain:

$$
\begin{aligned}
& 1=\delta \Theta\left(\sigma_{L}+\Theta \mu\right) \Rightarrow \sigma_{L}=\frac{1}{\delta \Theta}-\Theta \mu \\
& \frac{d \sigma_{L}}{d \Theta}=-\frac{1}{\delta \Theta^{2}}-\mu<0
\end{aligned}
$$


The derivative, Equation (30), shows that a currency devaluation reduces the wage share. The same analysis can be extended for the profit share:

$$
\begin{aligned}
& \frac{1}{\delta \Theta}=\sigma_{L}+\Theta \mu \Rightarrow \sigma_{K}=1-\frac{1}{\delta \Theta} \\
& \frac{d \sigma_{K}}{d \Theta}=\frac{1}{\delta \Theta^{2}}>0
\end{aligned}
$$

It can be seen in the derivative, Equation (32), that the profit share and the RER are positively related. Bearing these results in mind, we can now proceed to the analysis of Figure 6.

Let us start with the LWS region around the unstable solution $E 1^{\prime}$. Perturbations in any other direction will be amplified, as the system veers off the new equilibrium point. Devaluation shifts the initial short-term solution to the left of $E 1$, as devaluation reduces the wage share. Taking the scenario represented in Figure 6, if the initial short-term solution lies below (and to the left of) the separatrix crossing the new long-term equilibrium $E 1^{\prime}$, then devaluation reduces both $\sigma_{L}$ and $S$, thus initiating a vicious circle. Since in the LWS region technological progress is wage-led, a decrease in the wage share also reduces the pace of technological innovation, which reduces growth, undermines the bargaining power of the workers, thereby bringing down once again the wage share and so on. In contrast, given the inverse relationship between the wage share and the RER in the LWS region, a currency appreciation seem to be the most recommended policy measure for a country to boost technological catch-up and reach a more equal income distribution. In the LWS region, a currency appreciation increases the wage share, which intensifies technological changes and propels growth; fast growth rates favor workers during the bargaining process, thus augmenting the wage share anew and so forth, generating a virtuous circle of technological progress, a reduction of income inequality and growth.

As for the analysis of the HWS region around the stable point $E 2^{\prime}$, it can be seen that devaluation shifts the equilibrium solution from $E 2$ to $E 2^{\prime}$. Since in this region the technological progress is profit-led, devaluation accelerates the pace of technical change, due to an increase in the profit rate, and hence worsens income inequality as a consequence. Alternatively, a currency appreciation slows down the technological catching-up process and redistributes domestic income in favor of the workers. In short, perturbations in the stable solution induce $S$ and $\sigma_{L}$ to move in opposite directions. This raises an important question: if we assume that the long-term growth of output is positively related to relative technological capabilities $(S)$ and the wage share $\left(\sigma_{L}\right)$, as described in Equation (13), and given the fact 
that the RER is positively related to $S$ in the HWS region and negatively related to $\sigma_{L}$, then what is the net impact of a devaluation on long-term growth? In the case of the LWS region, apart from the unlikely scenario where the system solution is moving along the separatrix, it is easy to see that if both $S$ and $\sigma_{L}$ increase (decrease) simultaneously in a virtuous (vicious) circle, then the long-term growth rate must also increase (decrease). However, in the case of the HWS region, the impact of a currency devaluation on long-term growth is ambiguous. The next section seeks to shed some light on this issue.

\section{The net impact of currency devaluation on long-term growth}

In order to evaluate the net impact of devaluation on long-term growth, let us return to Equation (13). By substituting Equation (13) into Equation (10) we have extended Thirwall's Law with endogenous elasticities as follows:

$$
y_{B P}=\frac{\varepsilon}{\pi} z=\left(\beta_{0}+\beta_{1} \sigma_{L}+\beta_{2} S\right) z
$$

The assessment of an impact of a currency depreciation on long-term growth must consider not only how changes in the RER affect relative technological capabilities $(S)$ and the wage share $\left(\sigma_{L}\right)$ but also the values of the parameters $\beta_{0}, \beta_{1}$ and $\beta_{2}$.

That said, let us now illustrate in Figure 7 below the net impact of a currency devaluation on long-term growth in the HWS region.

\section{[FIGURE 7 ABOUT HERE]}

In Figure 7, Equation (33) is represented in the first quadrant as a set of iso-growth curves, where each of which consists of a constant equilibrium growth rate in the space $\left(\sigma_{L}, S\right)$. The slope of these curves is given by $-\beta_{1} / \beta_{2}$.

As for the fourth quadrant, we must analyze the relationship between the RER and the equilibrium wage share in the HWS region $\left(\sigma_{L E 2}\right)$. Figure 6 shows that a currency devaluation reduces the wage share $\left(\sigma_{L E 2},-\sigma_{L E 2}<0\right)$. Hence, the RER and the equilibrium wage share in the HWS region $\left(\sigma_{L E 2}\right)$ are inversely related. In Figure 7 the relationship between the RER and $\sigma_{L E 2}$ is assumed to be linear for convenience.

In the second quadrant we have the relationship between the RER and the country's longterm relative technological capabilities level in the HWS region. It follows from Figure 6 that 
a currency devaluation increases a country's technological capabilities $\left(S_{E 2},-S_{E 2}>0\right)$. Thus, the RER and $S_{E 2}$ are positively related.

Having defined the relations between the endogenous variables, we can now analyze the scenario represented in Figure 7. It starts in the third quadrant with a currency devaluation $\left(\Theta_{E 2},-\Theta_{E 2}>0\right)$. In the fourth quadrant, we can see that the devaluation reduces the wage share in income $\left(\sigma_{L E 2},-\sigma_{L E 2}<0\right)$. On the other hand, the same devaluation increases the technological progress in the home country $\left(S_{E 2},-S_{E 2}>0\right)$, as shown in the second quadrant. Finally, in the first quadrant, since the iso-growth curves are sufficiently elastic-

that is, the slope of the iso-growth curves is sufficiently low in absolute value $\left|\beta_{1} / \beta_{2}\right|$-we can say that a currency devaluation spurs growth in the long-term $\left(y_{B P 2}-y_{B P 1}>0\right)$. That is, the more gradual (steep) the iso-growth curve, the more (less) likely it is that a currency devaluation manages to spur growth.

To sum up, this model shows that the net effect of a currency devaluation on long-term growth is ambiguous which makes it an empirical issue. Nonetheless, our model contributes to the literature by mapping out conditions under which the net effect of a currency devaluation on economic growth is either positive or negative and hence sheds light on a number of testable hypotheses that could be explored in future empirical research. It depends not only on the parameters of the model, but also on the magnitude in absolute values of changes in its endogenous variables, namely the technology gap and the wage share, and on the type of technological progress regime, that is wage-led or profit-led. Therefore, policymakers should take into account the idiosyncrasies of the economy before they decide to promote economic recovery or simply boost growth by the use of currency devaluations.

\section{Concluding comments}

This paper contributes to the literature on BPCG models, income distribution and technological innovation by developing a theoretical framework in which the non-price competitiveness of the economy is determined by the coupled dynamics of relative technological capabilities and income inequality. An increase in the pace of technological innovation induces improvements in the non-price competitiveness of domestic goods. On the other hand, an increase in the wage share of income changes the consumption pattern of both capitalists and workers, and hence also affects the non-price competitiveness of the economy. Therefore, although the vast majority of existing studies indicate a positive relationship between the exchange rate and growth, in this analysis we point out a number of adverse 
effects of a currency devaluation on the structure of the economy that have been neglected in the literature to date, thus implying that the net impact of an exchange rate devaluation on growth is ambiguous. Our model establishes a set of conditions under which a currency devaluation can either boost or harm growth in the long-term. When the wage share is relatively low, given the constraints imposed on the parameters in this analysis, without loss of generality, a currency appreciation seems to be more effective to boost technical change, the wage share of income and economic growth. On the other hand, when the wage share is relatively high, a devaluation will cause technological innovation and the wage share to move in opposite directions, which means that the net impact of a real devaluation on long-term growth can go either way depending on the parameters of the model.

Ergo, our theoretical model is particularly relevant in terms of exchange rate policies, as it sheds light on relevant features of the institutional framework (for example, trade unions and labor market regulation) and the structure of the economy (for example, different classes with different consumption patterns) which should not be neglected in policymaking.

\section{Acknowledgments}

The authors are grateful to Ricardo Araújo, Mark Setterfield, Nigel Allington, Julia Torracca and two anonymous referees for their helpful comments on this paper. The usual disclaimer applies.

\section{Disclosure statement}

No potential conflict of interest was reported by the authors.

\section{References}

Aguirre, Alvaro, and Cesar Calderón. 2005. 'Real Exchange Rate Misalignments and Economic Performance.' Central Bank of Chile, Economic Research Division.

Amable, Bruno, and Bart Verspagen. 1995. 'The Role of Technology in Market Share Dynamics.' Applied Economics 27 2: 197-204.

Araujo, Ricardo. 2012. 'New Insights from a Structural Economic Dynamic Approach to Balance-of-Payment Constrained Growth.' In Models of Balance of Payments Constrained Growth: History, Theory and Empirical Evidence, edited by Soukiazis, Elias and Pedro Cerqueira, 217-238. New York: Palgrave MacMillan 
Araújo, Ricardo, and Gilberto Tadeu Lima. 2007. 'A Structural Economic Dynamics Approach to Balance-of-Payments Constrained Growth.' Cambridge Journal of Economics 31 5: 755-774.

Barbosa-Filho, Nelson. 2006. 'Exchange rates, growth and inflation.' Annual Conference on Development and Change, Campos do Jordão, November.

Blecker, Robert. 1989. 'International Competition, Income Distribution and Economic Growth.' Cambridge Journal of Economics 13: 395-412.

Bohman, Helena, and Désirée Nilsson. 2007. 'Income Inequality As A Determinant Of Trade Flows.' International Journal of Applied Economics 4 1: 40-59 .

Carvalho, Veridiana and Gilberto Tadeu Lima. 2009. 'A Restrição Externa e a Perda de Dinamismo da Economia Brasileira: Investigando as Relações Entre Estrutura Produtiva e Crescimento Econômico.' Economia e Sociedade 18 1: 31-60.

Dalgin, Muhammed, Vitor Trindade and Devashish Mitra. 2008. 'Inequality, Nonhomothetic Preferences, and Trade: A Gravity Approach.' Southern Economic Journal 74 3: 747-774. Dixon, Robert, and Anthony Thirlwall. 1975. 'A Model of Regional Growth Rate Differences Along Kaldorian Lines.' Oxford Economic Papers 27: 201-14.

Dollar, David. 1992. 'Outward-Oriented Developing Economies Really Do Grow More Rapidly: Evidence From 95 LDCS 1976-1985.' Economic Development and Cultural Change 40: 523-44.

Fagerberg, Jan. 1998. 'International Competitiveness.' The Economic Journal 98 391: 355374.

Francois, Joseph, and Seth Kaplan. 1996. 'Aggregate Demand Shifts, Income Distribution, and the Linder Hypothesis.' Review of Economics and Statistics 78 2: 244-50.

Ferrari, Marcos, Fábio Freitas, and Nelson Barbosa-Filho, N. 2013. 'A Taxa de Câmbio Real e a Restrição Externa: Uma Proposta de Releitura com Elasticidades Endógenas.' Revista de Economia Política 33 1: 60-81.

Furtado, Celso. 1968. Subdesenvolvimento e Estagnação na América Latina. Rio de Janeiro: Civilização Brasileira.

Furtado, Celso. 1969. Um Projeto Para o Brasil, Rio de Janeiro: Saga.

Gala, Paulo. 2007. 'Real Exchange Rate Levels and Economic Development: Theoretical Analysis and Econometric Evidence.' Cambridge Journal of Economics 32 2: 273-288.

Glyn, Andrew, Alan Hughes, Alain Lipietz, and Ajit Singh. 1990. 'The Rise And Fall of The Golden Age.' In The Golden Age of Capitalism, edited by Marglin, Stephen, and Juliet Schor, 39-125. Clarendon Press. 
Gouvea, Rafael, and Gilberto Tadeu Lima. 2010. 'Structural Change, Balance-of-Payments Constraint, and Economic Growth: Evidence From The Multisectoral Thirlwall's Law.' Journal of Post Keynesian Economics 33 1: 169-204.

Gouvea, Rafael, and Gilberto Tadeu Lima. 2013. 'Balance-of-Payments-Constrained Growth in a Multisectoral Framework: A Panel Data Investigation.' Journal of Economic Studies 40 2: $240-254$.

Hughes, Kirsty. 1986. 'Exports and Innovation: A Simultaneous Model.' European Economic Review 30: 383-399.

Kaldor, Nicholas. 1966. 'Causes of The Slow Rate of Economic Growth of The United Kingdom.' Inaugural Lecture. Cambridge University Press

Kalecki, Michal. 1971. Selected Essays on the Dynamics of the Capitalist Economy. Cambridge: Cambridge University Press.

Léon-Ledesma, Miguel. 2002. 'Accumulation, Innovation And Catching-Up: An Extended Cumulative Growth Model.' Cambridge Journal of Economics 26: 201-216.

Lima, Gilberto Tadeu. 2004. 'Endogenous Technological Innovation, Capital Accumulation and Distributional Dynamics.' Metroeconomica 55 4: 386-408.

Lima, Gilberto Tadeu, and Gabriel Porcile. 2013. 'Economic Growth and Income Distribution With Heterogeneous Preferences on The Real Exchange Rate.' Journal of Post Keynesian Economics 35 4: 651-674.

Loayza, Norman, Pablo Fajnzylber, and Cesar Calderón. 2004. 'Economic Growth in Latin America and The Caribbean: Stylized Facts, Explanations, and Forecasts.' Central Bank of Chile, Working Papers, $\mathrm{n}^{\mathrm{o}}$ 265, June.

McCombie, John. 2011. 'Criticisms and Defences of The Balance Of Payments Constrained Growth Model: Some Old, Some New.' PSL Quarterly Review 64 259: 353-392.

McCombie, John, and Anthony Thirlwall. 1994. Economic Growth and The Balance-ofPayments Constraint. New York: St. Martin's Press.

McCombie, John, and Anthony Thirlwall. 1997. 'Economic Growth and The Balance-ofPayments Constraint Revisited.' In Markets, Unemployment and Economic Policy: Essays in Honour of Geoff Harcout, edited by Arestis, Phillip, Gabriel Palma, and Malcolm Sawyer. New York: Routledge.

McCombie, John, and Anthony Thirlwall. 1999. 'Growth in an International Context: A Post Keynesian View.' In Foundations of International Economics: Post Keynesian Perspectives, edited by Deprez, Johan, and John Harvey, 35-90. London and New York: Routledge. 
Missio, Fabricio. and Frederico Jayme Jr. 2012. 'Structural Heterogeneity and Endogeneity of Elasticities on The Balance-of-Payments Constrained Growth Model.' In Models of Balance of Payments Constrained Growth: History, Theory and Empirical Evidence, edited by Soukiazis, Elias, and Pedro Cerqueira. New York: Palgrave MacMillan.

Mitra, Davashish, and Vitor Trindade. 2003. 'Inequality and Trade. NBER Working Paper No. 10087.

Moreno-Brid, Juan Carlos. 1998. 'On Capital Flows and The Balance-of-Payments Constrained Growth Model.' Journal of Post Keynesian Economics 21 2: 283-289.

Moreno-Brid, Juan Carlos. 1999. 'Mexico's Economic Growth and The Balance-OfPayments Constraint: A Cointegration Analysis.' International Review of Applied Economics 13 2: 150-159.

Moreno-Brid, Juan Carlos, and Esteban Pérez. 1999. 'Balance-of-Payments-Constrained Growth in Central America: 1950-96.' Journal of Post Keynesian Economics 22 1: 131147.

Perraton, Jonathan. 2003. 'Balance-of-Payments Constrained Economic Growth and Developing Countries: An Examination of Thirlwall's Hypothesis.' International Review of Applied Economics 17 1: 1-22.

Porcile, Gabriel, Marcos Vinicius Dutra, and Antonio Meirelles. 2007. 'Technology Gap, Real Wages, and Learning in a Balance-of-Payments Constrained Growth Model.' Journal of Post Keynesian Economics 29 3: 473-500.

Porcile, Gabriel, and Gilberto Tadeu Lima. 2010. 'Real Exchange Rate and Elasticity of Labour Supply in a Balance-of-Payments Constrained Macrodynamics.' Cambridge Journal of Economics 34: 1019-1039.

Razin, Ofair, and Susan Collins. 1997. 'Real Exchange Rate Misalignments and Growth.' NBER Working Paper 6147.

Razmi, Arslan. 2005. 'Balance of Payments Constrained Growth Model: The Case of India.' Journal of Post Keynesian Economics 27 4: 655-687.

Rodrik, Dani. 2008. 'The Real Exchange Rate and Economic Growth.' Brookings Papers on Economic Activity 2008 2: 365-412.

Setterfield, Mark. 1997. “'History Versus Equilibrium' and The Theory of Economic Growth." Cambridge Journal of Economics 21 3: 365-378.

Setterfield, Mark. 2006. “Thirlwall's Law and Palley's Pitfalls: A Reconsideration.” In Growth and Economic Development: Essays in Honour of A.P. Thirlwall, edited by Arestis, Philip, John McCombie, and Roger Vickerman. Cheltenham: Edward Elgar. 
Soukiazis, Elias, Pedro Cerqueira, and Micaela Antunes. 2013. 'Growth Rates Constrained By Internal and External Imbalances and The Role of Relative Prices: Empirical Evidence From Portugal.' Journal of Post Keynesian Economics 36 2: 275-298.

Soukiazis, Elias, Pedro Cerqueira, and Micaela Antunes. 2014. 'Explaining Italy's Economic Growth: A Balance-of-Payments Approach With Internal and External Imbalances and Non-Neutral Relative Prices,' Economic Modelling 40: 334-341.

Tavares, Maria da Conceição, and José Serra. 1976. 'Além da Estagnação: Uma Discussão Sobre o Estilo de Desenvolvimento Recente do Brasil.' In América Latina, ensaios de interpretação econômica, edited by Serra José, 210-251. Rio de Janeiro: Paz e Terra.

Thirlwall, Anthony. 1979. 'The Balance-of-Payments Constraint as an Explanation of International Growth Rate Differences.' Banca Nazionale del Lavoro Quarterly Review, 128: 45-53.

Thirlwall, Anthony. 2011. 'Balance-of-Payments Constrained Growth Models: History and Overview.' PSL Quartely Review 64 259: 307-351.

\section{Appendix}

The terms of the Jacobian matrix are:

$J_{11}=-\alpha_{3}<0$

$J_{12}=\rho_{1}-2 \alpha_{2}=\alpha_{2}\left(1-\Theta \mu-2 \sigma_{L}\right)=2 \alpha_{2}\left(\sigma_{L}^{*}-\sigma_{L}\right) \gtrless 0$

$J_{21}=\theta \gamma_{2}>0$

$J_{22}=-\theta \gamma_{1}<0$ 
Figures

Figure 1. The locus $\dot{S}=0$

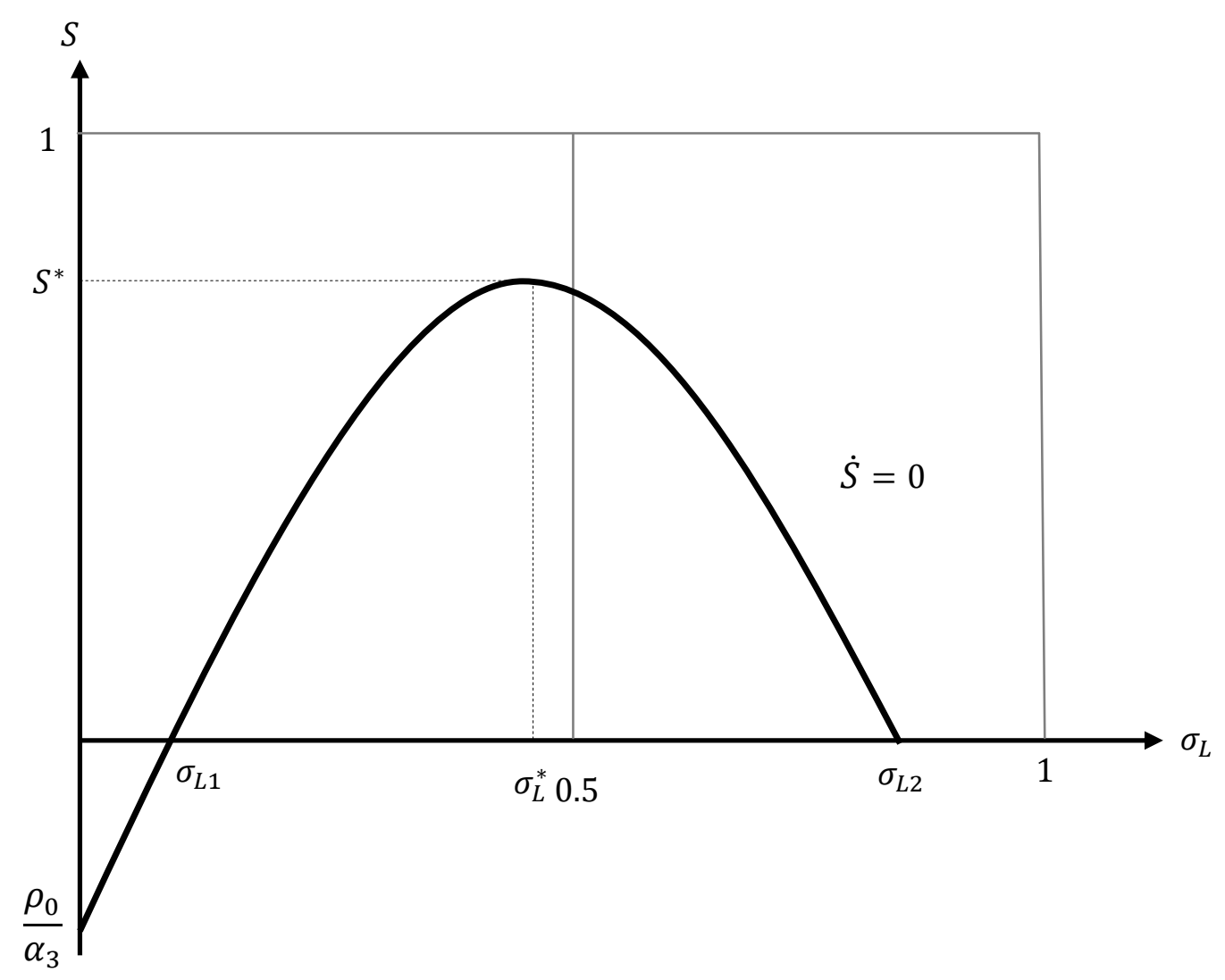


Figure 2. The locus $\dot{\sigma}_{L}=0$

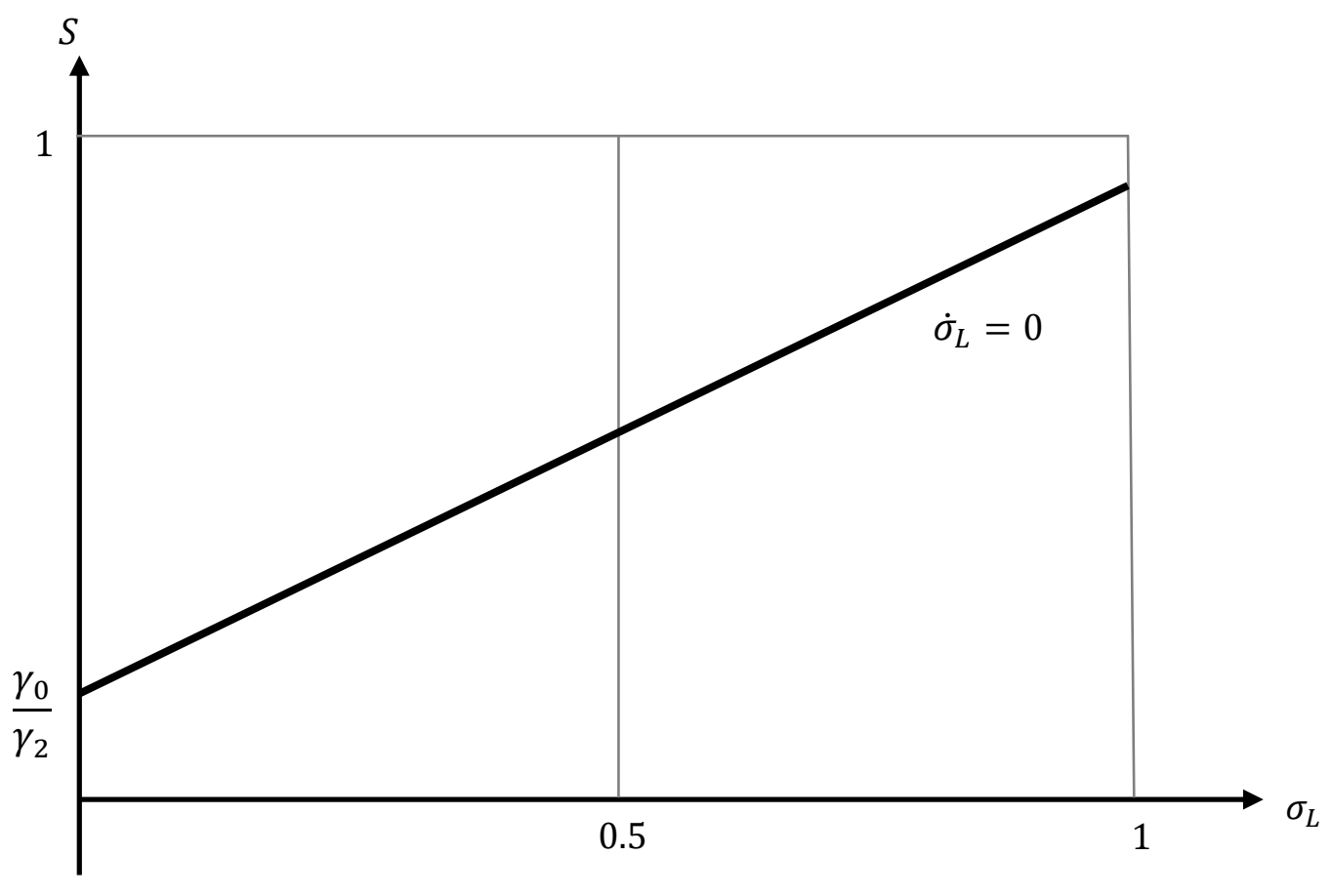


Figure 3. The loci $\dot{S}=0$ and $\dot{\sigma}_{L}=0$

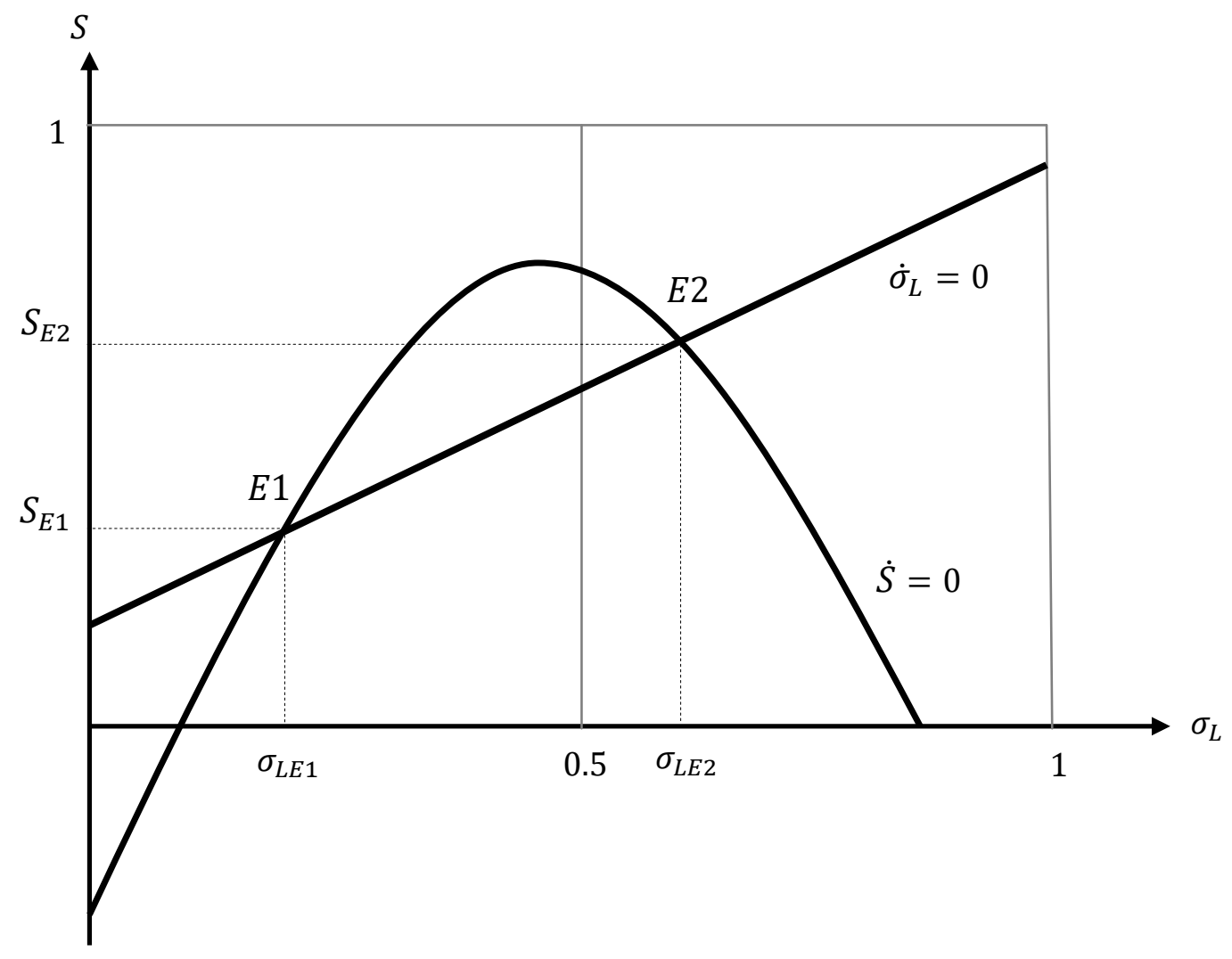


Figure 4. The impact of an undervaluation in locus $\dot{S}=0$

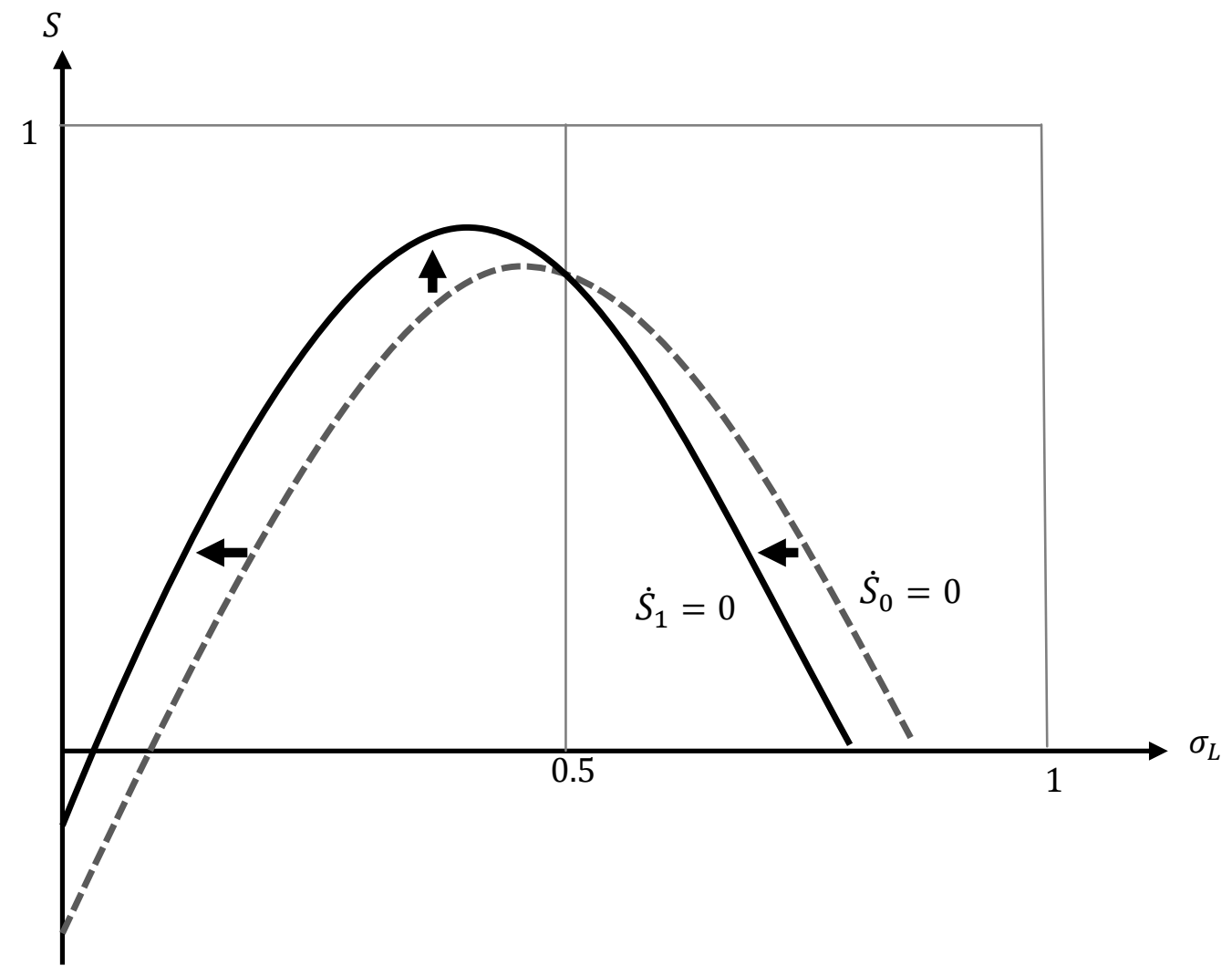


Figure 5. The impact of an undervaluation on locus $\dot{\sigma}_{L}=0$

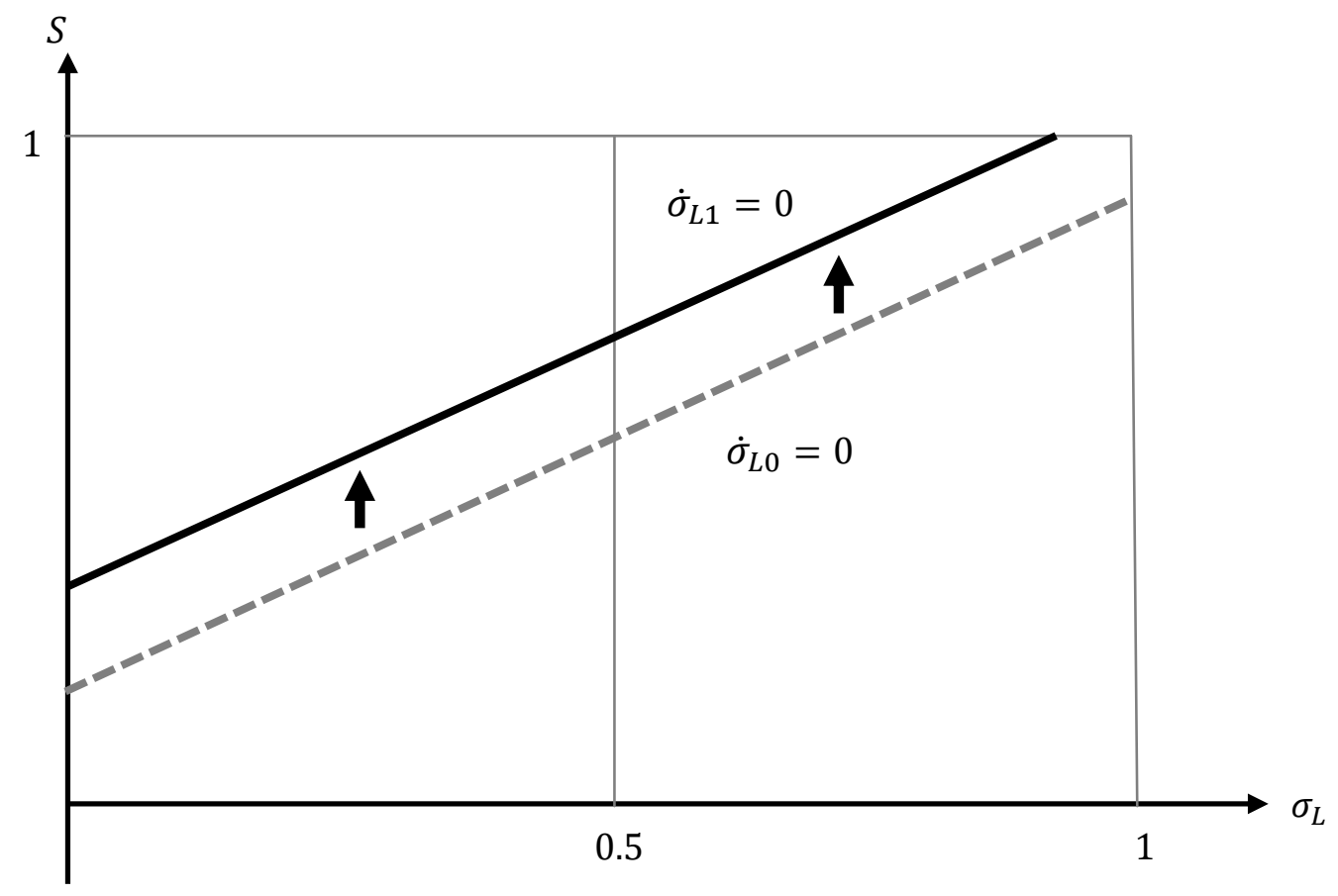


Figure 6. The impact of a devaluation on the dynamics between $S$ and $\sigma_{L}$

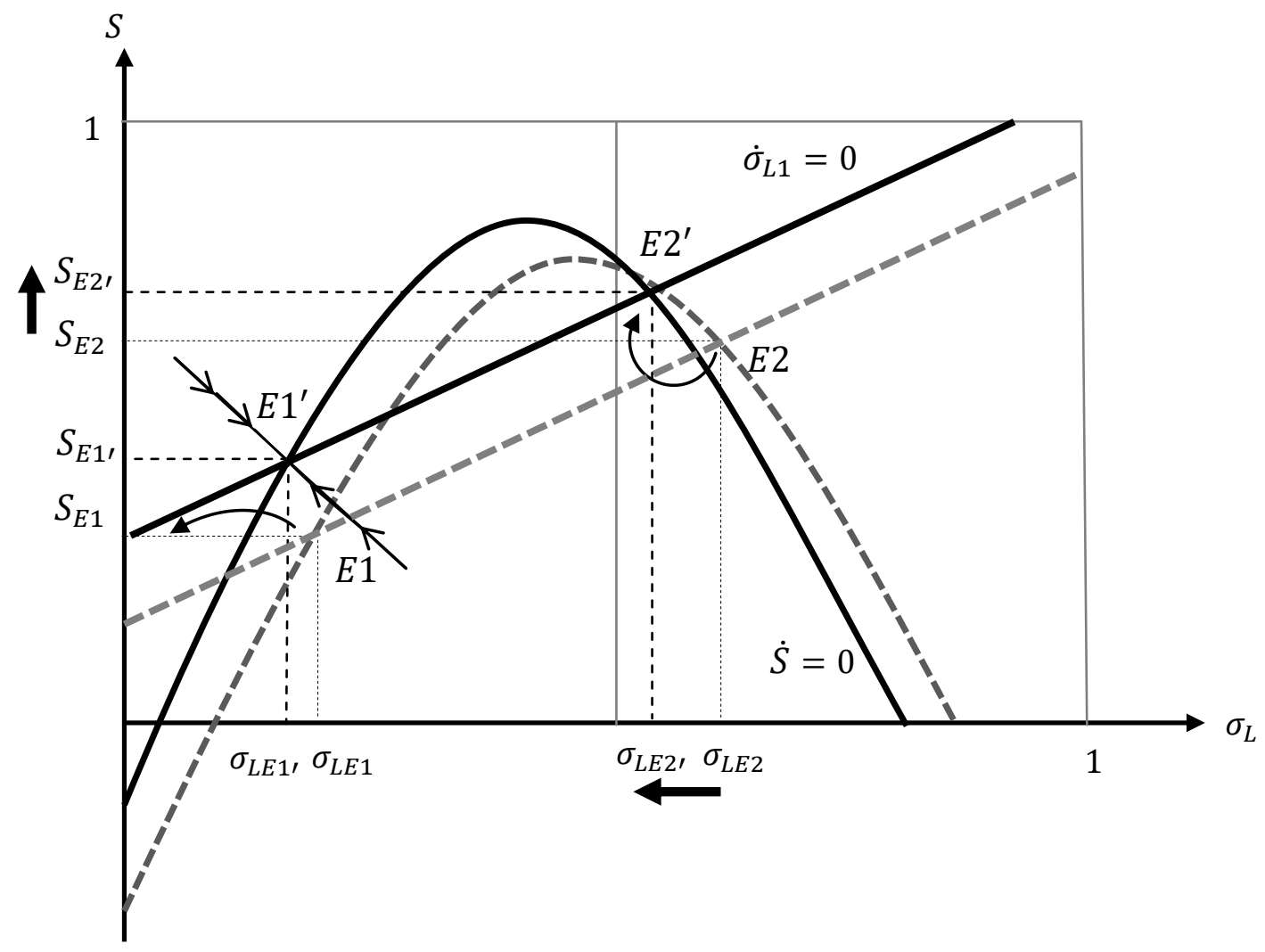


Figure 7. The impact of a currency devaluation on long-term growth

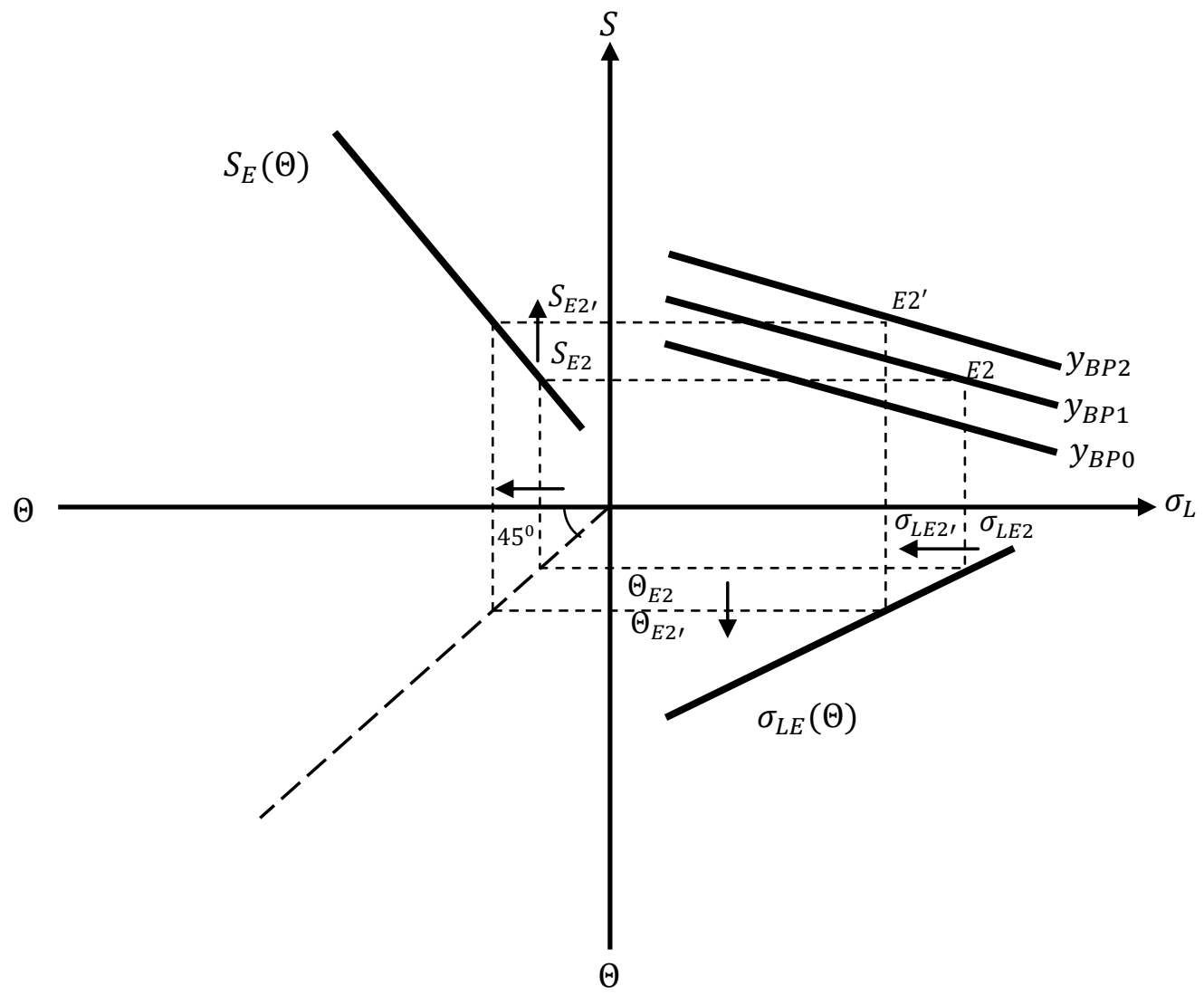

